\title{
Competitive Strategy Analysis to Increase Consumer Purchasing Decisions on Minimarket Business
}

\author{
Agus Supandi Soegoto ${ }^{1 *}$, Herman Karamoy ${ }^{2}$ \\ *Corresponding author
}

\begin{abstract}
The growth of the minimarket business in Indonesia is high-speed and exciting. As a result, the competition is very tight. This study aims to analyze the effect of product quality, price discounts, and servicescape on a consumer purchasing decision. This research uses associative descriptive methods and multiple linear regression analysis techniques. The research sample is to minimarket consumers in the cities of Manado, Tomohon, and Bitung. These results indicate that for consumers, the three variables are the main elements considered when shopping at the minimarket. The right management strategy will improve consumers' decision to buy products, thereby increasing profits and maintaining business sustainability. Management should always have attention to product quality by combining the right price discounts and servicescape to increase purchases, high profits, and superiority in competition.
\end{abstract}

Keywords: product quality, price discounts, servicescape, purchase decision, minimarket JEL Classification: M21, M31

\begin{abstract}
Abstrak. Pertumbuhan bisnis minimarket di Indonesia sangat cepat dan menarik. Akibatnya persaingan menjadi sangat ketat. Penelitian ini bertujuan untuk menganalisis pengaruh kualitas produk, diskon harga dan servicescape terhadap keputusan pembelian konsumen. Metode penelitian deskriptif asosiatif, dan tehnik analisis regresi linier berganda. Sample penelitian konsumen minimarket di kota Manado, Tomohon, dan Bitung. Hasil ini menunjukkan bahwa bagi konsumen ketiga variabel merupakan unsur utama yang dipertimbangkan saat berbelanja di minimarket. Strategi manajemen yang tepat akan meningkatkan keputusan konsumen membeli produk, sehingga meningkatkan laba, dan dapat mempertahankan keberlanjutan usaha. Management sebaiknya selalu memperhatikan kualitas produk dengan mengkombinasikan diskon harga dan servicescape yang tepat, untuk meningkatkan pembelian, laba yang tinggi dan keunggulan dalam persaingan
\end{abstract}

Kata Kunci: kualitas produk, diskon harga, servicescape, keputusan pembelian, minimarket

\section{How to Cite:}

Soegoto, A. S., \& Karamoy, H. (2020). Competitive Strategy Analysis to Increase Consumer Purchasing Decisions on Minimarket Business. Etikonomi: Jurnal Ekonomi, 19(1), 119 - 130. https://doi.org/10.15408/etk.v19i1.14337. 


\section{Introduction}

This research aims to determine the use of competition strategies for minimarket managers in Indonesia, through competition in product quality, price discounts, and servicescape against consumer purchasing decisions, with a sample of three major cities in North Sulawesi, Indonesia. Previous research has focused more on distribution strategies, location, consumer attitudes, and service quality in retail businesses.

In Indonesia, retail business growth is speedy and has a positive impact on economic growth. Anggraini (2013) stated that the development of a minimarket in almost all major cities in Indonesia has an impact on economic development. Towards the last decade of the Millenium, however, the battleground has expanded to developing countries, where deregulations in the retail sector aimed at increasing foreign direct investment (FDI) have resulted in the proliferation of supermarket chains (Reardon \& Hopkins, 2006). Many investors are interested in investing in the hope that they will benefit through this fast-paced business. As a result, competition occurs, not only in the business between supermarkets, the competition also occurs between modern retailers and traditional shops that have the same customers (Suryadarma et al., 2007).

Modern minimarkets and retails (such as hypermarkets \& supermarkets) are currently attractive for consumers to shop, especially to meet their daily needs, the reason being the availability of products and locations that are very easy to reach, in addition to the atmosphere and the servicescape support for shopping. Amin \& Mahasan (2019) stated that consumers visit the modern retail store for several reasons such as variety, easy availability, and cleanliness with an additional facility of entertainment. The retail business, including the Minimarket business in North Sulawesi, is currently growing rapidly. The rapid growth of the retail business has caused the challenges of competition in the field of product marketing among business people to increase very sharply. Minimarket business in business expansion requires only relatively small capital, in contrast to the supermarket and hypermarkets businesses that require significant capital. As a result, the growth of the Minimarket business in North Sulawesi is speedy, and almost always exists in strategic places or new locations.

The consumptive nature of the people of North Sulawesi is high, causing interest in buying products offered by Minimarkets, Supermarkets, and Hypermarkets. This condition encourages entrepreneurs engaged in the retail business to be interested in expanding their businesses to become leaders in occupied markets such as the minimarket. The presence of Minimarkets such as Alfa Mart and Indo Maret increasingly crowded found in almost all villages in the Manado city. For example, Indomaret for 2015 is targeting to establish 50 Minimarket outlets in the Manado city. Emor \& Soegoto (2015) states Indomaret, in its business competition, must compete closely with similar shops/ outlets that have already operated in Manado cities such as Gelael, Freshmart Express, Daily-Mart, and 24-Mart.

The initial observation of the writer of Indomaret has several advantages offered to buyers, such as daily offerings of products that are relatively cheaper, diverse, and impose price discounts, which are not carried out by their closest competitors such as Daily Mart, 24-Mart, K-Mart. According to the author, the competitive strategy adopted though to be a 
source of competitive advantage from Indomaret to its closest competitors, which received a positive response from buyers at Indomaret. Table 1 shows the data on the development of Supermarket and Minimarket outlets in North Sulawesi in 2019.

Table 1. Supermarket and Mini-market in North Sulawesi

\begin{tabular}{ccccc}
\hline \multirow{2}{*}{ No. Supermarket } & \multicolumn{2}{c}{ Minimarket } \\
\cline { 2 - 5 } & Outlets & Amount & Outlets & Amount \\
\hline 1. & Hypermart & 3 & Indomaret & 182 \\
2. & Multimart & 5 & Alfamart & 147 \\
3. & Freshmart & 1 & Freshmart Express & 5 \\
4. & Transmart & 2 & Dailymart & 5 \\
5. & Jumbo & 5 & 24-Mart & 2 \\
6. & Golden & 1 & Golden & 1 \\
7. & Gelael & 1 & Gelael & 1 \\
8. & Fiesta & 2 & Sahabat Swalayan & 1 \\
\hline
\end{tabular}

Source: Data processing

Table 1 can be seen in the distribution of minimarkets and supermarkets in North Sulawesi in 2019 from the data collected from 8 minimarkets that use as samples to observe. When viewed in the minimarket business in North Sulawesi, based on the number of minimarket outlets that have been established, the number of outlets from Indomaret is the highest, 182 outlets compared to Alfamart with 147 outlets. The phenomenon of competition in the retail business at this time is the level of competition from world business people who are getting higher, and the markets that serve are increasingly narrow. The brand can use as an aggressive marketing tool to retain existing customers as well as to attract new customers (Ahmed, et.al. 2018). This means that Minimarket business entrepreneurs must always try to get a market share that is growing every day and increasingly narrowed due to intense competition from business people.

Competition between retailers is very tight to fight over buyers. The rapid growth of the minimarket franchise system also has an impact on high competition and new problems for stores with traditional retail. The managers try to excel in competition; the retail store's managers need to secure their competitive advantages to be successful. So, retailers offer different promotional activities such as product quality, price discount, and aftersales services to attract the customer (Leszczyc et al., 2000). In the context of competition like this, consumer purchases are unique because each person's preference for a product is different. In the retail field, the application of marketing strategies is critical to creating excellence in business competition. Marketing is an organizational function and a series of processes to create, communicate, and deliver value to customers and to manage customer relationships in ways that benefit the organization and its stakeholders. Kotler \& Keller (2009) defined marketing management as the art and science of choosing target markets and getting, keeping, 
and growing customers through creating, delivering, and communicating superior customer value.

Retail business is a set of business activities carried on to accomplish the exchange of goods and services for personal, family, or household use, whether performed in-store or by some form of non-store selling. Others define retailing as a combination of those activities that increase the product and services' value for the end-user. Retailing has both spectra of sales of products and the sale of services (Dhotre, 2010; Levy \& Weitz, 2009). Retailing includes all the activities in selling goods or services directly to final consumers for personal, nonbusiness use (Amit \& Kameshvari, 2012). Retail store is any business enterprise whose sales volume comes primarily from retailing. The previous definition emphasizes exchanges with end-users by increasing the value of goods and services by benefiting retail users.

Product quality is the totality of features and characteristics of a product or service that depends on its ability to satisfy the stated or implied needs of users (Kotler \& Armstrong, 2012). Product quality is a characteristic of a product or service that depends on its ability to meet and satisfy customer needs for the product used. McDonnel \& Hall (2008) stated that consumer perceptions of product quality would shape preferences and attitudes that will influence the decision to buy or not.

The consumers who are price sensitive for particular products and services are known as price takers' consumers (Wakefield \& Inman, 2003; Pi et al., 2011). Many economists assume that consumers are "price takers" and accept prices at "face value" or as given (Kotler \& Keller, 2009). This factor is relating the consumer's choices about shopping outlets to product prices in terms of price fairness and affordability, whether they purchase fresh food products or any other kind of product (Newholm et al. 2011). A discount is a discounted price given by the seller to the buyer of a product or service. Consumers are interested in getting a fair price, in the form of perceived value at the time of sale. Discount shops are retailers who intend to sell to the consumer branded goods at low prices continuously and working with the self-service system. Consumers assume that a product with a high price means that it has good quality, whereas if a low price has poor quality (Assauri, 2009). The price discount is a discount to the price of the product or service as a cost reduction in a buy-sell transaction conducted by consumers.

Servicescape for business people is one strategy to attract consumers' interest in shopping for products offered. Appropriate servicescape arrangement structured is expected to determine the success of a marketing program designed by retailers. Servicescape is a unity of the physical environment of a service that affects the consumer experience (McDonnel $\&$ Hall, 2008). Architectural design and related design elements are essential components of a servicescape. Servicescape is a physical environment in which a service meeting occurs that will affect consumers' perceptions of product offerings and subsequently on subjective responses and external responses, namely customer behavior to repurchase (Rosenbaum \& Massiah, 2011).

Consumers in shopping always confront with purchasing decisions. Consumer decision making is a process to integrate that combines knowledge to evaluate two or more alternative 
product choices, to choose one of them (Peter \& Olson, 2005). Consumer purchasing decisions are unique because each person's preference for a product is different. Purchasing decisions are consumer decisions that are influenced by several factors of financial conditions, product offerings, prices, location, promotions, and other factors, which form an attitude to conclude products offered for purchase (Schiffman \& Kanuk, 2008).

The novelty of this research is looking at the competition made by minimarket managers to excel through offering quality products, price discounts, and servicescape to maintain and improve consumer-purchasing decisions in the minimarket business. This topic is very little research that has been done before, especially in the retail business in Indonesia. Preliminary survey results show that some consumers are interested in shopping because of the low price strategy, some consumers are interested and deliberately looking for products that give a discounted price, or a comfortable shopping environment. The shopping interests of these consumers are the subjects in this study, mainly related to consumer decision making for purchasing products in the minimarket.

\section{Methods}

This research was conducted in the North Sulawesi, especially in the cities of Manado, Tomohon, and Bitung (three major cities in North Sulawesi), from February to October 2019. The associative descriptive research method aims to uncover the model of the relationship between the research variables. Predictable variables include Product quality, Price discounts, and servicescape as the independent variable $(\mathrm{X})$ and Customer Purchase Decisions as the dependent variable $(\mathrm{Y})$. The analysis technique uses multiple linear regressions.

The research data take randomly using the proportional sampling method so that respondents could represent the population. The population of this study is consumers who shop for minimarket. The sample used was 100 respondents, according to the specified criteria, were selected to test consumers' perceptions of purchasing decisions in the minimarket. The sample used proportionally on retail business in minimarkets such as Indomaret 20 respondents, Alfa-Mart 20 respondents, Fresh-Mart Express 20 respondents, Golden 20 respondents, Gelael 10 respondents, and Sahabat Swalayan 10 respondents. The purposive technique uses when the researchers select a sample based on several criteria (Cooper \& Schindler, 2006). Statistical analysis includes standard assumption tests, and hypothesis testing is performed F and t-test (significance level of 5\%) using SPSS 20. The estimation does predict changes/ responses from dependent variables to some independent variables. The mathematical equation of this research as follows:

$$
C P D_{i}=\alpha+\beta_{1} P q_{i}+\beta_{2} P d_{i}+\beta_{3} S c_{i}+\varepsilon_{i}
$$

Where: CPD is a consumer purchase decision; Pq is product quality; Pd is price discount, and $\mathrm{Sc}_{\mathrm{c}}$ is servicescape.

After reviewing the literature, this study proposes the following set of hypotheses regarding the consumer's minimarket preference for a purchase decision:

H1: Product quality, price discounts, servicescape allegedly influence customer purchase decisions. 
H2: Product quality partially affects the customer purchase decision.

H3: Price discount partially affects customer purchase decisions.

H4: Servicescape partially affects the customer purchase decision.

\section{Result and Discussion}

The results of data collection based on questionnaires distributed and returned by the research respondents are as follows: The questionnaire spread by $102(100 \%)$ and Questionnaires who did not return $2(2.00 \%)$, so the response rate of the questionnaire is $98.00 \%$, then the qualified questionnaires are from 100 respondents, which use as the sample in the study. The respondents of the current study are 46 men (46\%) and 54 women (54\%), as provided in Table 2. It indicates that consumers, who shop for the minimarket in North Sulawesi, are still dominated by women. The descriptive analysis of 100 respondents in Table 2 shows that the most significant number of respondents are 26-65 years old, which is $65 \%$; besides, 28 (28\%) respondents are 15-25 years old, and 7 (7\%) respondents are 66-75 years old, so young people and productive age is the dominant shoppers (93\%).

Table 2. Distribution of Sample

\begin{tabular}{|c|c|c|c|}
\hline Variable & Variables Categorie & Number & Percentage (\%) \\
\hline \multirow[t]{2}{*}{ Sexgroup } & Male & 46 & 46 \\
\hline & Female & 54 & 54 \\
\hline \multirow[t]{3}{*}{ Age Group } & $15-25$ & 28 & 28 \\
\hline & $26-65$ & 65 & 65 \\
\hline & $66-75$ & 7 & 7 \\
\hline \multirow[t]{3}{*}{ Education } & Bachelor's degree & 47 & 47 \\
\hline & Diploma degree & 30 & 30 \\
\hline & High school & 23 & 23 \\
\hline \multirow[t]{4}{*}{ Occupation } & Civil Servants & 29 & 29 \\
\hline & Entrepreneurs & 38 & 38 \\
\hline & Students & 22 & 22 \\
\hline & Other (Labor, farmers) & 11 & 11 \\
\hline \multirow[t]{4}{*}{ Income (month) } & IDR 200,000 - IDR. 999,000 & 14 & 14 \\
\hline & IDR 1,000,000 - IDR 4,999,000 & 55 & 55 \\
\hline & IDR 5,000,000 - IDR 9,999,000 & 23 & 23 \\
\hline & $>$ IDR $10,000,000$ & 8 & 8 \\
\hline
\end{tabular}

In the education level, $47 \%$ of respondents are a bachelor, and $30 \%$ of them are the diplomas. The education level of respondents is good (77\%), and can understand well the questionnaires that fill out. In Employment, $29 \%$ of respondents are Civil Servants, and 38\% of them are Entrepreneurs. Respondents who shop (67\%) have a fixed income, so they have purchasing power. The fixed income of respondents 55\% respondents IDR 1,000,000 - IDR 
4,999,000, and 23\% of them have income IDR 5,000,000 - IDR 9,999,000. Minimarket respondents have a potential purchasing power of $78 \%$, so this is an opportunity for minimarket management to increase their sales turnover using the right marketing strategy.

The growth of the minimarket business in North Sulawesi and other cities in Indonesia very fast drive by the increasing needs and attitudes of people who want to be practical in shopping coupled with the location of a minimarket that is increasingly approaching residential areas. In addition to the general minimarket established in residential areas, the supply of materials directly comes from distributors who are distributed directly to the warehouse or shop center (Fahirah, 2008). A minimarket is a shop-like place of business that has a maximum floor area of $200 \mathrm{~m} 2$, which sells direct goods for daily needs.

The test results of the research instruments are all valid and reliable. All items are valid questions having a value above the value of $r$-stat $>r$-table, and also, the value of $r$ is higher than the critical value that is above $0.30(>0.30)$. While the reliability test shows, all variables are reliable because it has Cronbach alpha values above the value of 0.60 or $>0.60$ (Malhotra, 2007). The value of Reliability (Alpha Cronbach) of each variable is product quality (0.775), price discounts (0.734), and Servicescape decision (0.80). Because of the value of each statement on the variable of Product quality, Price discounts, and Servicescape Cronbach Alpha value $>0.6$ so it is declared Reliable.

Table 3. The Regression Result

\begin{tabular}{lccc}
\hline \multicolumn{1}{c}{ Variable } & Coefficient & t-stat & Prob \\
\hline Constant & 4.165 & 2.087 & 0.022 \\
Product quality & 0.257 & 2.051 & 0.032 \\
Price discount & 0.503 & 3.085 & 0.004 \\
Servicescape & 0.406 & 3.290 & 0.003 \\
\hline R-square & 0.7016 & F-stat & 13.227 \\
\hline
\end{tabular}

The formulation of the hypothesis test with the level of significance used in this study for 5 percent or $\alpha=0.05$. The empirical result shows that from the $t$-test in Table 3 shows that all variables such as product quality, price discount, and servicescape have a positive impact on the customer purchase decision. The multiple linear regression equation as follows:

$$
C P D_{i}=4.165+0.257 P q_{i}+0.503 P d_{i}+0.406 S c_{i}+\varepsilon_{i}
$$

The F-test in Table 3 shows that F-stat $=13,227>$ F-table 3,12, hence it can conclude that product quality, price discounts, and servicescape have a positive impact on customer Purchase decision in minimarket. The coefficient of determination is the square of the correlation coefficient (R) or also known as $\mathrm{R}^{2}$. The coefficient of determination serves to determine how much influence Product quality, Price discounts, and servicescape on customer purchasing decisions. From the empirical result in Table 2, it knows that the coefficient of determination or $\mathrm{R}^{2}$ is 0.7016 or $70.16 \%$. This result shows that Product quality, Price discounts, and servicescape simultaneously imply the variable of customer purchasing decisions by $70.16 \%$. 
So, product quality, price discounts, and servicescape have major implications for improving customer purchasing decisions because the quality of products that manage well, applied price discounts, and Servicescape enhancements expect to improve customer purchasing decisions. While the remaining $29.84 \%$ is the influence of other variables not examined outside the quality of Products and Servicescape.

The results of this study show that Product quality, Price discounts, and servicescape have a effect on the Purchase decision of minimarket customers in North Sulawesi. The results of this study fit according to the opinion of Grewal \& Levy (2010) that green marketing as strategic efforts that can be done by the company's management to provide eco-goods and services to the target consumers. Another opinion is that green product development has various benefits to firms in terms of increasing sustainable environmental benefits and the awareness of the brand image of the firm (Yan \& Yazdanifard, 2014). According to Ankit \& Mayur (2013), most marketers use green advertising with pollution-free messages to attract consumers' attention; it can enhance their knowledge of the quality of the product.

The results of the analysis of the implementation of the strategy of product quality, price discounts, and servicescape on consumer purchasing decisions in the minimarket business that there is a positive and significant effect. Thus the application of the right strategy used by minimarket managers will be able to improve consumer-purchasing decisions. The retail business in North Sulawesi is currently overgrowing, so competition for buyers has become tighter. Some retailers are unable to compete that eventually had to be closed down because they were unable to attract consumer buying interest, for example, Coco supermarket, Borobudur supermarket, GIANT, and Circle K. They forced to close their businesses due to losses as a consequence of being unable to compete to get buyers due to very tight competition due to the fast-growing supermarket and minimarket businesses.

Product quality is one of the strategies implemented by retail businesses to attract consumers to buy and stay in business competition. Products as an essential part of the marketing mix contribute to improving business performance. Previous research on the practice of marketing mix shows a good impact on the implementation of the marketing mix with firm performance (Goi, 2009; Iskandar et al., 2015). Study shows that the adoption of marketing mix by the entrepreneur will enable them to have a competitive advantage to their competitors (Mukaila \& Adefemi, 2011). Product quality can increase consumer confidence in the company and encourage interest in buying products for consumers. In terms of product, the company shall be more active in updating product information (Sari, 2017).

Servicescape from the results of this study has a positive and significant influence on consumer purchasing decisions. Servicescape refers to the style and appearance of the physical environment and also includes other elements of the service environment that shape the experience of a consumer (McDonnel \& Hall, 2008). Servicescape is the differentiator and characteristic of a unified physical environment of the services offered and affects the perception of a consumer. An essential component of a servicescape, namely architectural design and related supporting elements.

In the current competitive environment, consumer preferences become very relied 
upon by companies to win the competition. The ultimate goal is the decision to buy products offered by retailers. Consumer purchasing decisions become something unique and essential because everyone's preferences for products offered by retailers differ. The results of this study indicate that consumer-purchasing decisions influence by Product Quality, Discounted Prices, and Servicescape (physical environment), and there are also other considerations according to the level of consumer interest. Purchasing decisions are the result of consumer selection of two or more choices of bids received by consumers (Schiffman \& Kanuk, 2008). However, this result is different from the study by Amanah \& Harahap (2018) shows that the price discount does not an impact on the purchase decision.

The competition in the minimarket and supermarket businesses is greatly influenced by the high level of consumer interest (Chen \& Chang, 2012). Although the price is the key factor that consumers concerned the most (Nasution et al., 2019), however, other factors way consumers purchasing intentions such as attitudes, reference groups, and others (Chang et al., 2010). Other competition challenges are increased competition in the field of product marketing (product diversity) and lower prices (price discounts) among retail businesses due to advances in technology and information. Consequently, consumers are more interested in the best offers offered by retail businesses. For example, Indo Maret, Golden Supermarket, and Fresh Mart have their customer segments and market share that are loyal in making purchases (transactions) to meet the daily needs of customers. The consumers who are of a low-price sensitive are willing to pay more on the product than the variation of the price (Eze \& Ndubizi, 2013).

The tight business competition for managers of minimarkets and supermarkets today causes the store or outlet managers are always required to be able to innovate to attract consumers, and their businesses have their advantages, meaning that the desire to shop for consumers remains high when they are in their shopping areas. At this stage, consumer purchases become something unique that is supposed to get special attention, because each consumer's buying preferences and interests for a product are always different and drive by the best offer, offered by managers. Performance seen from the speed, quality, service, and value the meaning of speed in the process of working that have reliable quality and excellent service and value see from the achievement of performance or not (Soegoto \& Kadisi (2017). Highperformance businesses differentiate on all that looks attractive to have, along with other independent activities that focuses effort on functional groups on essential and meaningful matters in the marketplace (Day, 1999).

\section{Conclusion}

This research conducts a study mainly on how the application of marketing strategies especially in the minimarket business in the face of very competitive competition with other parties, conducted in North Sulawesi, Indonesia. Several studies have conducted on supermarkets, but studies that specifically examine minimarkets are still lacking in number, especially for competition between minimarkets in Indonesia. The result of this research is that there is simultaneously and partially a positive impact of product quality, price discounts, 
and servicescape on customer purchasing decisions. Definite preferences on product quality, price discounts, and servicescape have a significant effect on consumer purchasing decisions. Consumers who visit feel happy because they feel minimarket service providers can meet their needs, this will affect consumers' impressions that will drive purchasing decisions. The right management strategy will improve consumers' decision to buy products, thereby increasing profits and maintaining business sustainability. Management should always have attention to product quality by combining the right price discounts and servicescape to increase purchases, high profits, and superior in competition.

\section{References}

Ahmed, A., Talreja, S., \& Naz, H. (2018). Building Consumer-Based Brand Equity in Retail Banks: A Quantitative Study on a Pakistani Star Bank. Etikonomi, 17(2), 253-264. DOI: htttps://doi.org/10.15408/etk.v17i2.6728.

Amanah, D., \& Harahap, D. A. (2018). Examining the Effect of Product Assortment and Price Discount Toward Online Purchase Decision of University Student in Indonesia. Jurnal Manajemen dan Kewirausahaan, 20(2), 99-104. https://doi.org/10.9744. jmk.20.2.99-104.

Amin, S., \& Mahasan, S. S. (2019). Difference Between Consumer Preferences to Choose Between the Traditional Retailing and Modern Retailing. Journal of Business and Retail Management Research (JBRMR), 14(1), 63-70.

Amit, P \& Kameshvari, B. (2012). A Study on Consumer Behaviour of Organized and Un Organized Retail Outlets in Vadodara City. International Journal of Engineering and Management Sciences, 3(4), 466-474.

Ankit, G., \& Mayur, R. Green Marketing: Impact of Green Advertising on Consumer Purchase Intention. Advances in Management, 6(9), 14-17.

Assauri, S. (2009). Manajemen Pemasaran (Marketing Management.) Jakarta: Rajawali Press.

Anggraini, P. (2013). The Effect of Minimarket Location Distribution on Traditional Market Service Outreach in Banyumanik District. Journal of Urban Area Development, 9(1), 97-109.

Chang, M. L., Lai, M., \& Wu, W. Y. (2010). The Influences of Shopping Motivation on Adolescent Online-Shopping Perceptions. African Journal of Business Management, 4 (13), 2728-2742.

Chen, Y. S., \& Chang, C. H. (2012). Enhance Green Purchase Intentions The Roles of Green Perceived Value, Green Perceived Risk, and Green Trust. Management Decision, 50(3), 502-520.

Cooper, D. R. \& Schindler, P. S.(2006). Business Research Methods (9 ${ }^{\text {th }}$ Edition). New York: Mc-Graw Hill, Irwin.

Day, G.S. (1999). Market-Driven Strategy, Processes Creating Values. New York: The Free Press.

Dhotre, M. (2010). Channel Management and Retail Marketing. Mumbai: Himalaya Publishing House. 
Emor, R. Y. S \& Soegoto, A. S. (2015). The Influence of Price Discounts, Brand Image, and Servicescape Towards The Purchase Decision of Consumers Indomaret Tanjung Batu. Journal EMBA, 3(2), 738-748.

Eze, U. C., \& Ndubisi, N. O. (2013) Green Buyer Behavior: Evidence from Asia Consumers. Journal of Asian and African Studies, 48(4), 413-426.

Fahirah F. (2008). Market Analysis of the Mini Market Project. Journal SMARTek, 6(3), 154163.

Goi, C. L. (2009). A Review of Marketing Mix: 4Ps or More? International Journal of Marketing Studies, 1(1), 2-15.

Grewal, D., \& Levy, M. (2010). Marketing (2nd edition). New York: McGraw Hill.

Iskandar, D., Nurmalina, R., \& Riani, E. (2015). The Effect of Service, Product Quality, and Perceived Value on Customer Purchase Intention and Satisfaction. Indonesian Journal of Business and Entrepreneurship, 1(2), 51-62. https://doi.org/10.17358/ijbe.1.2.51.

Kotler, P., \& Armstrong, G. (2012). Principles of Marketing. New Jersey: Pearson Education.

Kotler, P., \& Keller, K. L. (2009). Marketing Management. New Jersey: Pearson, PrenticeHall.

Leszczyc, P. T. L. P., Sinha, A., \& Timmermans, H. J. P. (2000). Consumer Store Choice Dynamics: an Analysis of the Competitive Market Structure for Grocery Stores. Journal of Retailing, 76(3), 323-345. https://doi.org/10.1016/S0022-4359(00)00033-6.

Levy, M., \& Weitz, B. A. (2009). Retailing Management. New York: McGraw Hill-Irwin.

Malhotra, N. K. (2007). Marketing Research an Applied Orientation. New Jersey: Pearson Education International.

McDonnel, A., \& Hall, C. M. (2008). A Framework for The Evaluation of Winery Servicescapes a New Zealand Case. Journal of Tourism and Cultural Heritage, 6(2), 231-247.

Mukaila A. A, \& J. Adefemi, B. (2011). Marketing Mix Practice as a Determinant of Entrepreneurial Business Performance. International Journal of Business and Management, 7(1), 205-214.

Nasution, D. T. P., Rossanty, Y., Ariffin, K. H. K., \& Zaini, N. I. B. M. (2019). An Empirical Examination of the Factors InfluencingConsumer's Purchase Intention toward online Shopping. Journal of Business and Retail Management Research (JBRMR), 13(4), 14-29. https://doi.org/10.24052/JBRMR/V13IS04/ART-02.

Newholm, T., McGoldrick, P., Keeling, K., Macaulay, L., \& Doherty, J. (2011). Multi-Story Trust and Online Retailer Strategies. The International Review of Retail, Distribution and Consumer Research, 14(4), 437-456.

Peter, J. P., \& Olson, J. C. (2005). Consumer Behaviour \& Marketing Strategy (7th ed). New York: McGraw-Hill Companies, Inc.

Pi, S. M., Liao, H. L., Liu, S. H,\& Lee, L. S. (2011). Factors Influencing the Behaviour of Online Group Purchasing in Taiwan. African Journal of Business Management, 5(16), 7120-7129. 
Reardon, T., \& Hopkins, R. (2006). The Supermarket Revolution in Developing Countries: Policies to Address Emerging Tensions among Supermarkets, Suppliers and Traditional Retailers. European Journal of Development Research, 18(4), 522-545.

Rosenbaum, M. S., \& Massiah, C. (2011). An Expanded Servicescape Perspective. Journal of Service Management, 22(4), 471-490. https://doi.org/10.1080/02642069.2017.1402890.

Sari, R. P. (2017). Marketing Mix Implementation in Small Medium Enterprises: A Study of Galeristorey Online Business. Etikonomi. 16(1), 115-125. https://oi.org/ 10.15408/ etk.v16i1.3950.

Schiffman, L. G., \& Kanuk, L. (2008). Consumer Behavior. New Jersey: Pearson Education.

Soegoto, A. S., \& Kadisi, R. E. (2017). Entrepreneurial Government Attitude Towards The Performance of Local Government Officials. Etikonomi, 16(2), 207-220. https:// doi. org/10.15408/etk.v16i2.4968

Suryadarma D, A. Poesoro, S. Budiyati, Akhmadi, and M. Rosfadhila. (2007). Impact of Supermarkets on Traditional Markets and Retailers in Indonesia's Urban Centers. The SMERU Research Institute Working Paper, 11(62).

Wakefield, L., \& Inman, J. (2003). Situational Price Sensitivity. The Role of Consumption Occasion, Social Context, and Income. Journal of Retailing, 79 (4), 199-212. https:// doi.org/10.1016/j.retai.2003.09.004.

Yan, Y.K. \& R. Yazdanifard (2014). The Concept of Green Marketing and Green Product Development on Consumer Buying Approach. Global Journal of Commerce \& Management Perspective, 3(2), 33-38. 